\title{
Four-dimensional flow magnetic resonance imaging: Just beautiful pictures or clinical relevant analysis?
}

\author{
Martin Grabenwoger, MD, ${ }^{\mathrm{a}, \mathrm{b}, \mathrm{c}}$ and Bernhard Winkler, $\mathrm{MD}^{\mathrm{a}, \mathrm{b}}$
}

\footnotetext{
From the ${ }^{\mathrm{a}}$ Department of Cardio-Vascular Surgery, Hospital Hietzing, Vienna, Austria; ${ }^{\mathrm{b}}$ Karl Landsteiner Institute for Cardio-Vascular Research, Vienna, Austria; and ${ }^{\mathrm{c}}$ Sigmund Freud Private University, Vienna, Austria. Disclosures: Authors have nothing to disclose with regard to commercial support.

Received for publication Nov 28, 2017; accepted for publication Dec 18, 2017; available ahead of print Feb 3, 2018.

Address for reprints: Martin Grabenwoger, MD, Department of Cardio-Vascular Surgery, Hospital Hietzing, Wolkersbergenstraße 1, A-1130 Vienna, Austria (E-mail: martin.grabenwoeger@wienkav.at).

J Thorac Cardiovasc Surg 2018;155:2252-3

$0022-5223 / \$ 36.00$

Copyright $(2) 2017$ by The American Association for Thoracic Surgery

https://doi.org/10.1016/j.jtcvs.2017.12.075
}

In this issue of the Journal, Bollache and colleagues ${ }^{1}$ investigated by 4-dimensional (4-D) flow magnetic resonance imaging (MRI) changes in pre- and postsurgical aortic wall shear stress (WSS) in patients undergoing aortic valve and/or proximal thoracic aortic replacement.

Out of a large 4D flow MRI database, 33 patients with a full data set (pre- and postsurgery) were identified. The surgery included aortic valve replacements, valve-sparing aortic root reconstructions, Bentall operations, as well as hemiarch replacements. In addition, a matched cohort of 20 "control" aortopathy patients without surgical intervention was investigated.

The main findings of this study are that peak aortic WSS and at-risk tissue area decreased after surgery in patients who underwent biological aortic valve replacement whereas aortic WSS was increased distal to the Dacron graft after root surgery. No differences were observed between hemiarch replacement and ascending aortic repair. The authors conclude that different proximal aortic interventions induce distinct changes in aortic WSS. This noninvasive imaging biomarker may help to identify patients at risk for future events and optimize operative strategies.

The authors have to be congratulated for the sophisticated elaboration of the study. However, because of the heterogeneity of interventions, small sample size, and the lack of follow-up on clinical outcome, no strong evidence can be obtained with respect to the clinical relevance of the findings. The transformation from "beautiful pictures" to clinical relevant results has to be demonstrated in the future. It has to be proven that aortic WSS plays a role in disease progression indicated by expansion or pathologic alteration of the aorta. Increase in aortic WSS distal to an incompliant Dacron prosthesis after replacement of the native elastic tissue is a well-known phenomenon. Retrograde type A aortic dissections after placement of a rigid endovascular stent graft in the proximal descending aorta may be explained by the increase in aortic WSS proximal to the stent graft. wall stiffness.

\section{References}

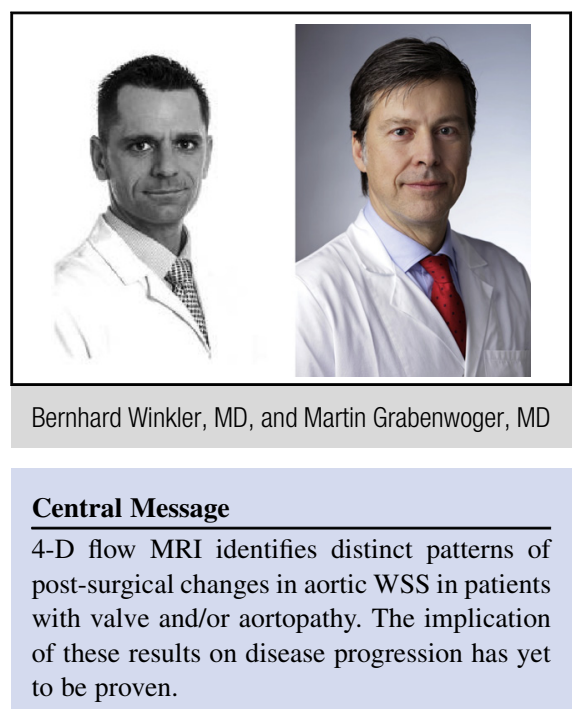

See Article page 2277.

Previous studies ${ }^{2}$ demonstrated that aortic root versus aortic valve replacement alone had more impact on WSS than additional hemiarch repair. Van Ooij and colleagues ${ }^{3}$ showed in 2015 using 4-D flow MRI that in bicuspid valve patients the greatest level of WSS was found on the outer curvature of the ascending aorta. Illapani et colleagues ${ }^{4}$ examined the correlation between aortic wall stiffness and aortic WSS. The study demonstrated a negative trend with no significant correlation between aortic WSS and aortic

Bollache and colleagues ${ }^{1}$ have to be complimented for this first work using noninvasive 4D flow MRI data combined with a 3-dimensional method with the goal to establish a noninvasive biomarker supporting clinical decision making in patients with aortic disease. 4D flow MRI has the potential to identifying patients at high risk for future events and to optimize surgical procedures. However, the implication of these distinct patterns of aortic WSS on the progression of aortopathy and on risk assessment has to be investigated in future studies.

1. Bollache E, Fedak PWM, van Ooij P, Rahman O, Malaisrie SC, McCarthy PM, et al. Perioperative evaluation of regional aortic wall shear stress patterns in patients undergoing aortic valve and/or proximal thoracic aortic replacement. J Thorac Cardiovasc Surg. 2018;155:2277-86.e2.

2. Malaisrie SC, Duncan BF, Mehta CK, Badiwala MV, Rinewalt D, Kruse J, et al The addition of hemiarch replacement to aortic root surgery does not affect safety. J Thorac Cardiovasc Surg. 2015;150:118-24.e2. 
3. van Ooij P, Potters WV, Collins J, Carr M, Carr J, Malaisrie SC, et al. Characterization of abnormal wall shear stress using 4D flow MRI in human bicuspid aortopathy. Ann Biomed Eng. 2015;43:1385-97.
4. Illapani V, Garcia J, Mazumder R, White R, Mark1 M, Kolipaka A. Quantification and comparison of 4D flow MRI derived wall shear stress and MRE derived wall shear stiffness of abdominal aorta. J Cardiovasc Magn Reson. 2016;18(suppl 1):P360.

Access to The Journal of Thoracic and Cardiovascular Surgery Online is reserved for print subscribers!

Full-text access to The Journal of Thoracic and Cardiovascular Surgery Online is available for all print subscribers. To activate your individual online subscription, please visit The Journal of Thoracic and Cardiovascular Surgery Online, point your browser to http://www.mosby.com/jtcvs, follow the prompts to activate your online access, and follow the instructions. To activate your account, you will need your subscriber account number, which you can find on your mailing label (note: the number of digits in your subscriber account number varies from 6 to 10 ). See the example below in which the subscriber account number has been circled:

\section{Sample mailing label}

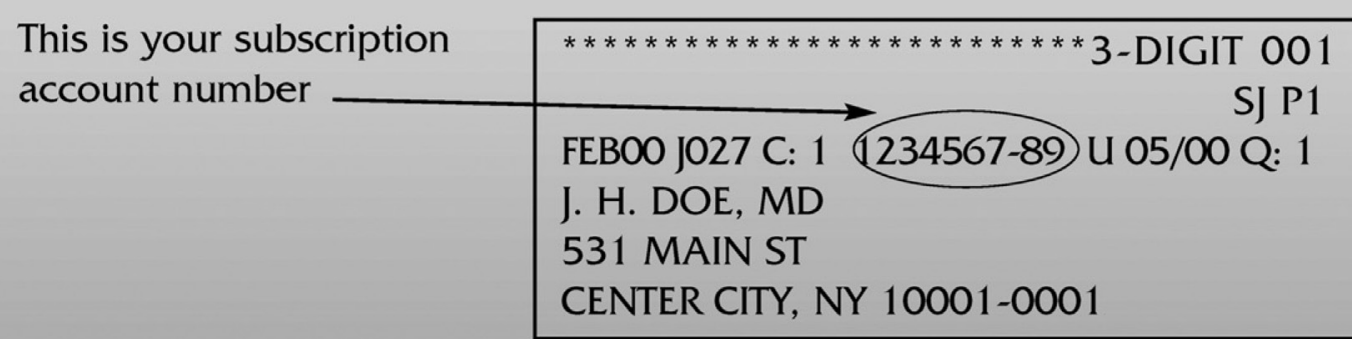

Personal subscriptions to The Journal of Thoracic and Cardiovascular Surgery Online are for individual use only and may not be transferred. Use of The Journal of Thoracic and Cardiovascular Surgery Online is subject to agreement to the terms and conditions as indicated online. 